\title{
MARINE BIODIVERSITY OF INDONESIA; LARVAL FISH PERSPECTIVE
}

\author{
A. Syahailatua \\ Research Centre for Oceanography LIPI \\ Jl. Pasir Putih 1, Ancol Timur Jakarta 14430.e-mail: augy@oseanografi.lipi.go.id
}

\begin{abstract}
Marine life of Indonesia is very well known as a high diversity according to Ekman's hyphothesis. However, from the larva fish perspectives, this hypothesis seems to be rejected according to the comparative results of larval fish studies during the Snellius Expedition (1984-1985) in Banda Sea and the larval fish observation related to the East Australian Current (1998-1999) off New South Wales coast in Australian waters. Larval fish diversity from some previous studies over the world is also included. Several suggestions are also recommended to enhance our knowledge in marine biodiversity including improvement in marine biodiversity observation such as, research programs, field and laboratory facilities and numbers of taxonomists, and also collaborative works among research institutes, universities, and non-governmental organizations.
\end{abstract}

Keywords: Marine biodiversity, Larval fish, Indonesia

\section{INDONESIAN HOTSPOT OF MARINE BIODIVERSITY}

As a maritime country covering with $70 \%$ seawaters, and be situated in the Indo-West Pacific region, Indonesia is very well known as one tropical state in the faunistic centre according to Ekman's concept (Ekman, 1953). This concept was then developed by Briggs (1974) and Hayden et al. (1984). The attractiveness of marine biodiversity in Indonesia has been created numbers of expeditions and observations on fauna and flora long time before Indonesian state declared (Hutomo and Moosa, 2005), for instance, L'Uranie (1818-1819), Challenger (1872-1876), Siboga (1899-1900), Albatross (1906-1909), Snellius (1921-1930), Mortensen Kai Island (1922), and Mortensen Java-South Africa (1929). Therefore, Indonesian archipelago may be categorized as a hotspot of marine biodiversity in the world.

Most results on previous expeditions were concluded that Indonesian waters deposits a huge diversity of marine life. At least two evidences were approved this statement, one is diversity of stony coral ( $<80$ genera and $<450$ species) in the Indo-West Pacific (Veron, 1986) and the other is numbers of pomacentrid species (after Allen, 1975). Thus, the high biodiversity of Indonesia marine life is not only the slogan, but also this is reality.

From larval fish perspective, the hotspot of marine biodiversity in Indonesia faces vague impression. It is quite interesting to discuss and may raise a lot of questions. I think this perspective may little support Ekman' hypothesis. In general, larval fish studies in Indonesia are limited extremely, however many world studies on larvae referring to some previous findings of Delsman's works between 1921 and 1938 in Jawa Sea (Delsman, 1972). This paper is reviewed previous studies of larval fish in Indonesia waters, and also reported the Snellius Expedition finding on larval fish in Banda Sea (Soewito and Schalk, 1990), and then compared the larval fish study in Eastern Australia (Syahailatua, 2005, Figure 1). Therefore, the hotspot of marine biodiversity in Indonesia may be questioned from larval fish perspective. 


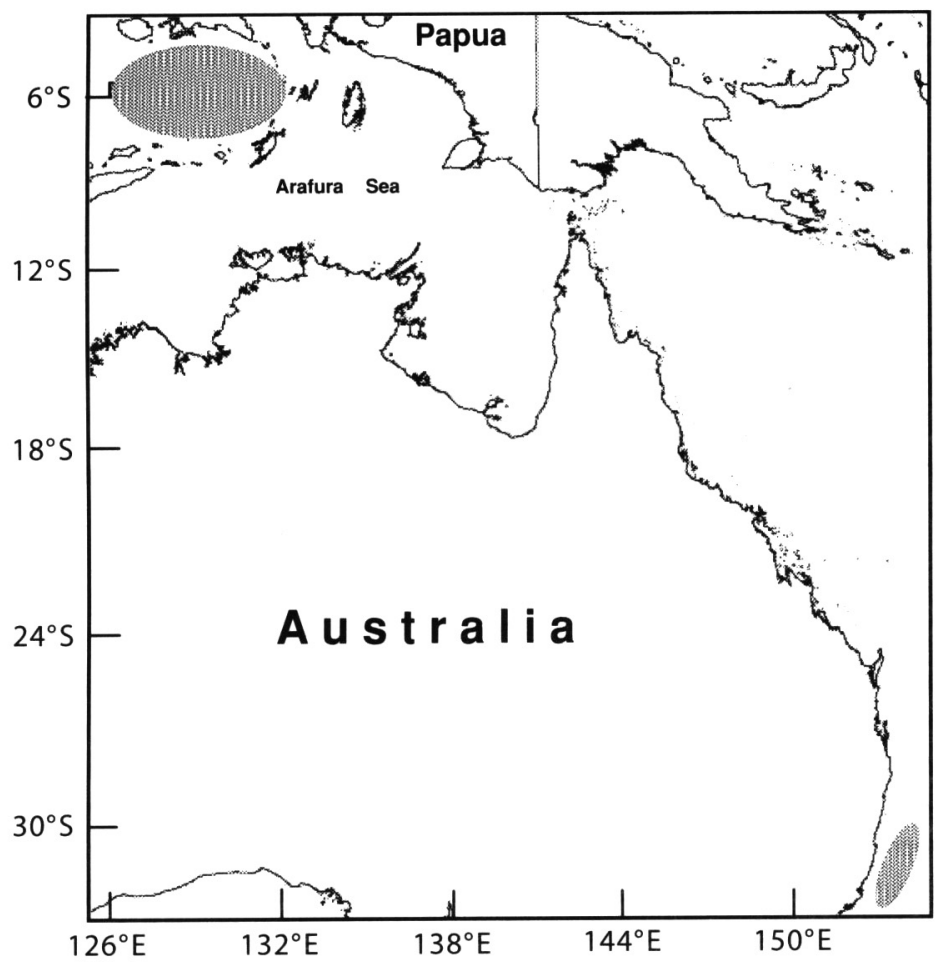

Figure 1. Map indicates sampling sites (shadow) in Banda Sea and Eastern Australia

\section{LARVAL FISH STUDIES IN INDONESIAN SEAS}

Dr H.C. Delsman can be called as a pioneer in larval fish study in Indonesia waters, and his works are really appreciated over the world. Most of his larva samples were collected in the coastal areas of Jawa sea, especially north Jawa, and he focused on taxonomic of fish eggs and larvae (Delsman, 1972). He described about 10 genera of fish eggs and larvae, and also illustrated them. Nowadays, his descriptions and illustrations on ichthyoplankton are commonly referred by many marine scientists.

Delsman's works on larval fish may be a spectacular evidence for marine ichthyologists in Indonesia as well as worldwide, unfortunately, information regarding larval fish in Indonesia, especially related to oceanographic feautures is very insignificant. The other study that compared to Delsman's works is probably larval collection during the Carlsberg Foundation Oceanographical Expedition 1928-1930 (Jespersen, 1942). The Calsberg's expedition had information on eel larvae (Lepthocephalus), and it has been re-examined since 2001 by Indonesian and Japanese scientists (Wouthuyzen, 2004, pers. comm.).
Till the end of the 20 century, larval fish information from Indonesian waters was updated by the results of larval study during the $2^{\text {nd }}$ of Snellius Expedition, 1984-1985 (Soewito and Schalk, 1990), however larval taxonomic from Indonesian waters is very limited.

\section{SNELLIUS EXPEDITION 1984-1985 (SOEWITO AND SCHALK, 1990).}

For the period of the Snellius Expedition in Banda Sea (1984-1985), larval fishes were sampled horizontally and vertically (up to $500 \mathrm{~m}$ depth) during day and night with a Rectangular Midwater Trawl (RMT) 1 (mesh $320 \mathrm{im}$ ) and RMT 8 (mesh $450 \mathrm{im}$ ) at 12 stations laid 128$134^{\circ} \mathrm{E}$ and $4-7^{\circ} \mathrm{S}$. There were 78 families identified from the samples, and families of Myctophidae and Gonostomidae were found abundantly during the southeast-monsoon (August 1984), while Acathuridae, Myctophidae and Gonostomidae were in great numbers of specimen during the nortwest-monsoon (February/March 1985). This study also concluded that larval composition of both seasons was slightly different due to possibility in water mass displacement (Soewito and Schalk, 1990). 


\section{COMPARISON OF LARVAL DIVERSITY BETWEEN LOW AND HIGH LATITUDES}

A comparative assessment of larval fish diversity from the two regions with latitudinal differences is very rare or maybe never done, because we understand that it should be different in numbers of taxa (species or families). However, I made this comparison due to a spectacular findings of larval fish in eastern Australia (EA) waters $\left(152^{\circ} 30^{\prime}-153^{\circ} \mathrm{E}\right.$ and $30-32^{\circ} \mathrm{S}$, see Fig. 1) observed during 2 weeks each of spring in November 1998 and of summer in January 1999. Larval samples were collected using neuston net (mesh $500 \mu \mathrm{m}$ ) and EZ net (multiple opened-closed net, mesh $500 \mu \mathrm{m}$ ) only during night (after sunset till sunrise) at 6 stations ( 3 sites each of $50 \mathrm{~m}$ and $100 \mathrm{~m}$ isobath). I identified 111 families with relative abundance of Carangidae, Labridae, Lutjanidae, Microcanthidae, Myctophidae and Scombridae were associated to the East Australian Current (EAC) or oceanic water masses, while the Callionymidae, Clupeidae, Platycephalidae, Sillaginidae and Teraponidae were mostly found in the surface or deep upwelled/uplifted water masses (Syahailatua, 2005).

I re-analyzed the two set of data, and found that EA had more families' numbers than BS and the ANOVA result shows significantly difference in family numbers (Fig. 2, Table 1). This evidence is supported by the Bray-Curtis similarity index $(<50 \%)$ of larval composition from both regions (Fig. 3). Also, from the combined data, 65 families were not caught from BS, while only 26 families were not found in EA. Conversely, the ShannonWiener diversity index was no significant difference indicating larval composition in family level comparable (Fig. 2, Table 1).

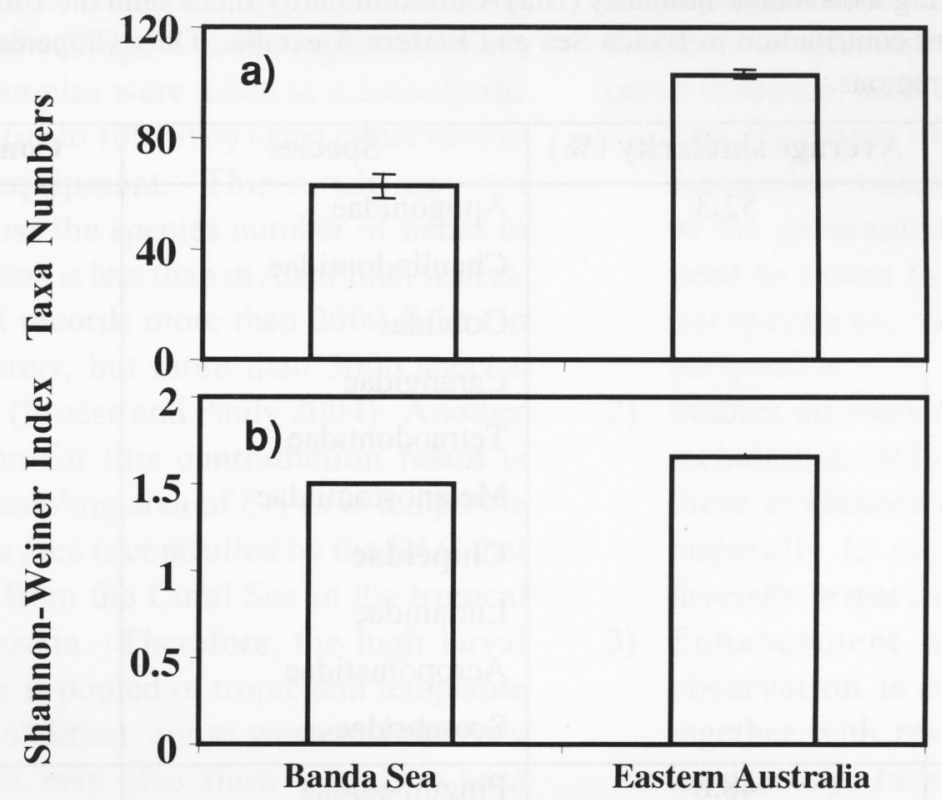

Figure 2. Total taxa numbers (a) and Shannon-Weiner Diversity Index (b) for larval samples of Banda Sea and Eastern Australia. The ANOVA results of these two sampling sites showing in Table 1.

Table 1. The ANOVA results of larval samples colleted in Banda Sea (1984-1985) and Eastern Australia (1998-1999). **=significant different at $\mathrm{P}<0.01 ; \mathrm{NS}=$ not significant at $\mathrm{P}>0.05$.

\begin{tabular}{|c|c|c|c|c|}
\hline Sources & DF & MS & $\mathbf{F}$ & $\mathbf{P}$ \\
\hline \multicolumn{5}{|c|}{ a. Taxa numbers } \\
\hline Regions & 1 & 1600.00 & 160.00 & $0.006 * *$ \\
\hline Residual & 2 & 10.00 & & \\
\hline Total & 3 & & & \\
\hline \multicolumn{5}{|c|}{ b. Shannon-Weiner Diversity Index } \\
\hline Regions & 1 & 0.25 & 0.00 & $0.999 \mathrm{NS}$ \\
\hline Residual & 2 & 254520.50 & & \\
\hline Total & 3 & 254520.75 & & \\
\hline
\end{tabular}




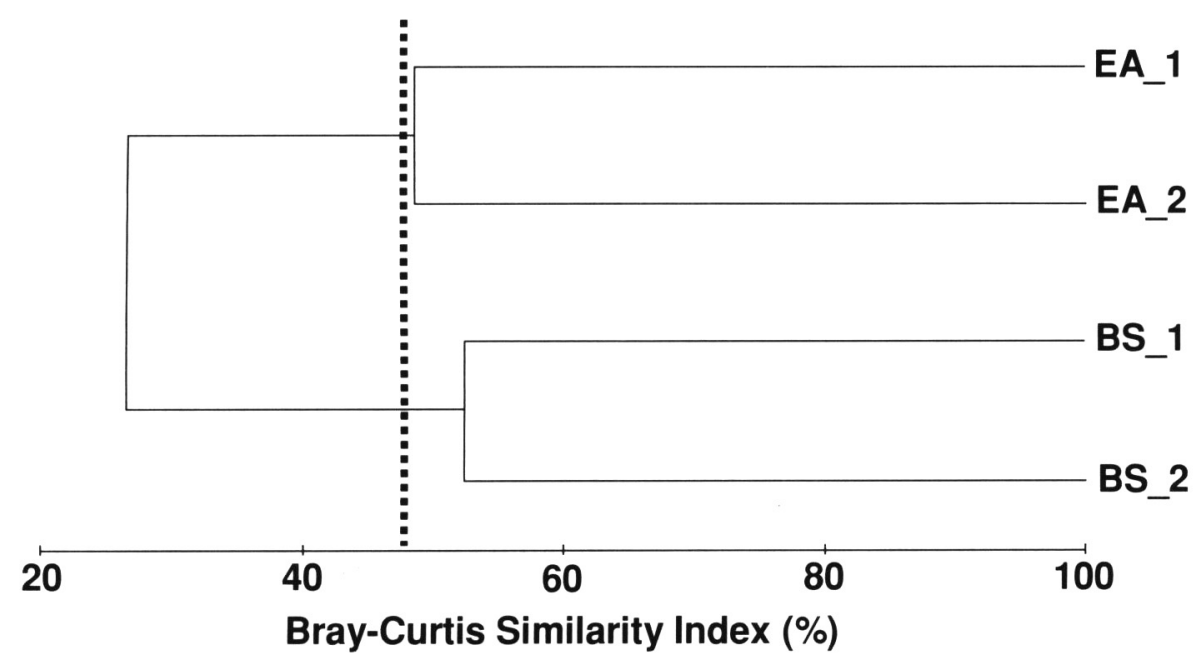

Figure 3. Cluster dendrogram shows the split of larval taxa from the two regions (EA, Eastern Australia; BS, Banda Sea) at less than $50 \%$ of Bray-Curtis Similarity Index. Percentage individual numbers were used and standardized without transformation.

Table 2. Simper results showing the average similarity (Bray-Curtis similarity Index) and the 10th dominant taxa giving the significant contribution in Banda Sea and Eastern Australia. Only Clupeidae was occurred dominantly in both regions.

\begin{tabular}{|l|r|l|r|}
\hline Region & Average similarity (\%) & \multicolumn{1}{|c|}{ Species } & Contrib. (\%) \\
\hline Banda Sea & 52.3 & Apogonidae & 11.7 \\
& & Chauliodontidae & 8.9 \\
& & Gobiidae & 7.2 \\
& & Carangidae & 6.3 \\
& & Tetraodontidae & 4.7 \\
& & Melanostomiidae & 4.6 \\
& & Clupeidae & 4.6 \\
& & Lutjanidae & 4.5 \\
& & Acropomatidae & 4.1 \\
& & Scombridae & 3.9 \\
\hline \multirow{5}{*}{ Eastern Australia } & \multirow{5}{*}{48.6} & Pinguipedidae & 6.0 \\
& & Serranidae & 5.9 \\
& & Acanthuridae & 4.1 \\
& & Dactylopteridae & 4.1 \\
& & Callionymidae & 4.1 \\
& & Gerreidae & 3.9 \\
& & Bothidae & 3.7 \\
& & Triglidae & 3.4 \\
& & Monacanthidae & 3.4 \\
& & Clupeidae & 3.3 \\
\hline & & &
\end{tabular}


Table 3. List of family numbers of larval fishes from western boundary current region

\begin{tabular}{|l|l|l|c|l|}
\hline Latitude & \multicolumn{1}{|c|}{$\begin{array}{c}\text { Western boundary } \\
\text { current region }\end{array}$} & \multicolumn{1}{|c|}{ Notes } & No. families & \multicolumn{1}{c|}{ Authors } \\
\hline $34 \mathrm{~S}$ & Off Sydney Australia & 2 cruises in 4 months & 111 & Smith \& Suthers 1999 \\
\hline $34 \mathrm{~S}$ & Off Sydney Australia & over 4 years & 119 & Gray \& Miskiewicz 2000 \\
\hline $27 \mathrm{~N}$ & Gulf of Mexico & over 33 days & 100 & Richards et al. 1993 \\
\hline & Great Barrier Reef & over 3 years & 99 & Leis \& Goldman 1987 \\
\hline $36 \mathrm{~N}$ & Cape Hatteras & Spring 1996 & 78 & Grothues \& Cowen 1999 \\
\hline $35 \mathrm{~N}-43 \mathrm{~N}$ & $\begin{array}{l}\text { East coast United States and } \\
\text { Canada }\end{array}$ & & 92 & Fahay 1983 \\
\hline $6 \mathrm{~S}$ & NE Brazil & 1 month & 74 & Ekau et al. 1999 \\
\hline $20 \mathrm{~S}$ & Brazil Current & 1978,1995 & 77 & Nonaka et al. 2000 \\
\hline $32 \mathrm{~S}$ & Angulas & 1 year & 139 & Beckley 1993 \\
\hline
\end{tabular}

Theoretically, high latitude region may have a large number of families or species, however the evidence of this assessment is not confirmed. It is fairly puzzling, because these two studies areas dominated by upwelling events during the sampling periods, and samples were taken at relatively the identical depth (up to $100 \mathrm{~m}$ ) by using rather similar mesh net of equipment. This result may not surprise, because the species number of fishes in Indonesian waters is less than in Australian waters. FishBase 2004 records more then 2000 fishes in Indonesian waters, but more than 3000 species from Australia (Froese and Pauly 2004). Another possible reason for this contradiction result is although the sampling area of EA as in temperate region, and this area is controlled by the EAC that moving south from the Coral Sea in the tropical region of Australia. Therefore, the high larval numbers in EA is pooled of tropic and temperate fish taxa. In addition, some western boundary current regions may also show a high in taxa number of larval fishes, however sometimes samples were taken more than 1 year (Table 3 ). All findings from those region are confirmed my findings in eastern Australia, and may supported this paper presuming.

\section{CONCLUSION REMARKS AND RECOMMENDATIONS}

A high in marine biodiversity of Indonesian waters is probably recognized elsewhere, and from some points of view, it is true, for example, species numbers of Pomacentrids (Allen 1975) or genera and species numbers of stony coral (Veron, 1986). However from larval fish perspectives, it seems that this biodiversity phenomenon is imprecise. This may open to discussion why it could be occurred. Numbers of speculation may be raised from this paper evidence, such as:

1) The statement of high marine diversity in Indonesian waters is a general perception due to the geographical facts, however we still need to assess this perception from several perspectives, for instance larval fish perspective.

2) Studies on marine biodiversity in Indonesia including larval fishes is in progress, therefore these evidences may vary frequently, and hopefully to support the statement 'high diversity in marine life'.

3) Enhancement in marine biodiversity observation is considered in some ways together with research programs, field and laboratory facilities and numbers of taxonomists.

4) Collaborative works among research institutes, universities, and non-governmental organizations should be designed to figure out the potential of marine biodiversity in Indonesia.

\section{REFERENCES}

Allen, G.R. 1975. Damselfishes of the South Seas. T.F.H. Publication, Neptune, New York: 240 pp.

Beckley, L. E.1993. Linefish larvae and Agulhas Current. In: L.E. Beckley, R.P. van der Elst (eds). Fish, fishes 
and fisheries proceedings of the $2^{\text {nd }}$ Linefish Symposium, Durham: 57-63.

Briggs, J. C.1974. Marine Zoogeography. McGraw Hill Book Company. pp

Delsman, H.C. 1972. Fish eggs and larvae from the Java Sea. Linnaeus Press, Amsterdam. 420 pp.

Ekau, W., P. Westhaus-Ekau and C. Medeiros. 1999. Large scale distribution of fish larvae in the continental shelf waters off NE-Brazil. Arch. Fish. Mar. Res., 47(2/3):183-200

Ekman, S. 1953. Zoogeography of the Sea. Sidgwick and Jackson, London: 417 pp

Fahay, M.P. 1983. Guide to the early stages of marine fishes occurring in the western north Atlantic Ocean, Cape Hatteras to the Southern Scotian Shelf. J. Northw. Atlant. Fish. Sci., 4:1-423

Froese, R and D. Pauly (Eds). 2004. FishBase 2004: Concepts, design and data sources. ICLARM, Los Baños, Laguna, Philippines.

Gray, C.A., and A.G. Miskiewicz. 2000. Larval fish assemblages in South-east Australia coastal waters: Seasonal and spatial structure. Estuar. Coast. Shelf. Sci., 50:549-570

Grothues, T. M and R.K. Cowen. 1999. Larval fish assemblages and water mass history in a major faunal transition zone. Cont. Shelf. Res., 19:11711198

Hayden, B.P., B.C. Ray and R. Dola. 1984. Classification of coastal and marine environments. Env. Cons., 11(3): 199-207.
Hutomo, M. and M.K. Moosa. 2005. Indonesian marine and coastal biodiversity: State of the arts of its present status. Indian. J. Mar. Sci., 34(1) :88-97

Jespersen, P. 1942. Indo-Pacific Lephocephalids of the genus Anguilla, systematic and biological studies. Dana-Report No. 22. The Carlberg Foundation.

Leis, J.M. and B. Goldman. 1987. Composition and distribution of larval fish assemblages in the Great Barrier Reef lagoon near Lizard Island, Australia. Aust. J. Mar. Freshw. Res., 38:211-223

Nonaka, R. H., Y. Matsuura and K. Suzuki. 2000. Seasonal variation in larval fish assemblages in relation to oceanographic condition in the Abrolhos Bank region off eastern Brazil. Fish. Bull., 98:767-784

Richards, W.J., M.G. McGowan, J. Leming, T. Lamkin and S. Kelly. 1993. Larval fish assemblages at the loop current boundary in the Gulf of Mexico. Bull. Mar. Sci., 53(2):475-537

Smith, K.A., and I.M. Suthers. 1999. Displacement of diverse ichthyoplankton assemblages by a coastal upwelling event on the Sydney shelf. Mar. Ecol. Prog. Ser., 176:49-62

Soewito and P.H. Schalk. 1990. Spatial and seasonal patterns in fish larvae distribution in the Banda Sea (Indonesia). Neth. J. Sea. Res. 25(4):591-600

Syahailatua, A. 2005. Biological oceanography of larval fish diversity and growth off eastern Australia. PhD thesis, University of New South Wales, Sydney Australia, 150 p.

Veron, J. E. N. 1986. Corals of Australia and the IndoPacific. Angus and Robertson publishers, Australia. 644 pp. 